\title{
PKM Training for Rural Economic Empowerment (Tree) dalam Pemberdayaan Masyarakat Pesisir Paiton Probolinggo
}

\author{
Rojabi Azharghany ${ }^{1}$, Syaiful Ghufron ${ }^{2}$, Moh. Fauzi ${ }^{3}$ \\ Universitas Nurul Jadid Probolinggo 123 \\ azharghany@gmail.com ${ }^{1}$, gufron.ummul@gmail.com²
}

Submission: 16/07/2021 Received: 30/08/2021 Published: 31/12/2021

\section{Keywords:}

coastal

communities, poverty,

TREE,

economic

empowerment
Katakunci: masyarakat pesisir, kemiskinan, TREE, penguatan ekonomi
Abstract. Should consist of one paragraph, should not exceed 300 words, and should contain the background and objective of the community service, method/approach/strategies of community service, its principal results, and its conclusions. The coastal community in Paiton District, Probolinggo Regency faces a development dilemma, even though the coastal area has great natural resource potential, especially the potential for coastal, fisheries and marine resources. This potential has not been exploited optimally and sustainably. Meanwhile, people, especially those living in coastal areas, Paiton District are still in high unemployment rates. The application of the Training for Rural Economic Empowerment (TREE) model is expected to overcome these problems. As a result, this empowerment program has implemented a development approach that ensures poor women and men get an inexhaustible resource of skills and knowledge that they can apply to increase their incomes and take a more active role in shaping their communities. Local development and gender approaches are heavily mainstreamed into the TREE program and therefore contribute to the empowerment of women and men. So that the Paiton coastal community can play a role in the development of their village through various fields including: economy, culture, social, religion, education, environment and health.

Abstrak. Masyarakat pesisir di Kecamatan Paiton, Kabupaten Probolinggo menghadapi dilema pembangunan, padahal kawasan pesisir memiliki potensi sumber daya alam besar, khususnya potensi sumber daya pesisir, perikanan, dan kelautan. Potensi ini belum tergarap secara optimal dan berkelanjutan. Sedangkan masyarakat khususnya yang tinggal di kawasan pesisir, Kecamatan Paiton masih berada dalam angka tingkat pengangguran yang tinggi. Penerapan model Training for Rural Economic Empowerment (TREE) diharapkan dapat mengatasi masalah tersebut. Hasilnya, program pemberdayaan ini telah menerapkan pendekatan pembangunan yang memastikan perempuan dan lakilaki miskin mendapatkan sumber daya yang tidak akan pernah hilang yaitu keterampilan dan pengetahuan yang dapat mereka 


\begin{abstract}
terapkan untuk meningkatkan pendapatan mereka dan mengambil peran lebih aktif dalam membentuk komunitas mereka. Pendekatan pembangunan lokal dan gender sangat diarusutamakan ke dalam program TREE dan oleh karena itu berkontribusi pada pemberdayaan perempuan dan laki-laki. Sehingga masyarakat pesisir Paiton dapat berperan dalam pembangunan desanya melalui berbagai bidang diantaranya: ekonomi, budaya, sosial, keagamaan, pendidikan, lingkungan dan kesehatan.
\end{abstract}

\title{
1 Pendahuluan
}

Kondisi masyarakat nelayan atau masyarakat pesisir di berbagai kawasan secara umum di tandai oleh adanya beberapa ciri, seperti kemiskinan, keterbelakangan sosial-budaya, rendahnya kualitas Sumber Daya Manusia (SDM). Hal ini di latar belakangi oleh sebagian besar penduduk hanya lulus sekolah dasar atau belum tamat sekolah dasar, dan lemahnya fungsi dari kelompok Usaha Kecil dan Menengah (UKM), koperasi atau kapasitas berorganisasi masyarakat.

Hal-hal seperti ini merupakan hambatan potensial bagi masyarakat nelayan atau pesisir untuk mendorong dinamika pembangunan di wilayahnya. Akibatnya, sering terjadi kelemahan bargaining position masyarakat pesisir dengan pihak-pihak lain di luar kawasan pesisir, sehingga mereka kurang memiliki kemampuan mengembangkan kapasitas dirinya dan organisasi atau kelembagaan sosial yang dimiliki sebagai sarana aktualisasi dalam membangun wilayahnya.

Padahal jika diamati secara progresif dan fundamental masyarakat nelayan memiliki berbagai potensi yang tidak dimiliki pada wilayah lain. Pertama, nelayan pendongkrak Gross National Product GNP dan Gross Domestic Product (GDP). Sebagai Negara kepulauan yang 70\% wilayahnya adalah lautan dengan garis pantai sepanjang 99.093 km (BIG:2013), Indonesia memilik sumber daya ekonomi kelautan khususnya sumberdaya perikanan yang melimpah. Di wilayah lautan Indonesia paling tidak terdapat 13 (tiga belas) sektor yang dapat dikembangkan dan dapat memberikan kontribusi bagi pendapatan nasional dan kesejahteraan masyarakat khususnya nelayan yang meliputi: perikanan tangkap, perikanan budidaya, industri pengolahan hasil budidaya, industri bioteknologi kelautan, pertambangan dan energi, pariwisata bahari, transportasi laut, industri dan jasa maritim, pulau-pulau kecil, sumber daya nonkonvensional, bangunan kelautan, benda-benda 
berharga dan warisan budaya, jasa lingkungan konversi dan biodiversitas (Retnowati, 2011).

Kontribusi sektor kelautan dan perikanan pada pendapatan nasional menunjukkan angka $14.7 \%$ dari total produk domistik broto (PDB) Indonesia, meskipun dibandingkan dengan negara lain semisal Jepang yang hanya memiliki garis pantai sepanjang 31.000 km dapat menyumbang 55 \% terhadap PDB. Selain itu, nilai ekspor Indonesia dari sektor kelautan dan perikanan mencapai 3,5 milyar dolar USA, walaupun masih kalah jika dibandingkan dengan Vietnam dan Thailand yang masing-maing mencapai 6,2 milyar dolar USA dan 8,6 milyar dolar USA sekalipun garis pantai mereka jauh lebih kecil jika dibandingkan dengan Indonesia (Nugroho, 2015).

Kedua, nelayan penyumbang geliat ekonomi kreatif. Salah satu model pemberdayaan masyarakat pesisir yang telah dikembangkan secara nasional oleh pemerintah adalah program Pemberdayaan Ekonomi Masyarakat Pesisir (PEMP) pada rentang tahun 2001 hingga 2008. Program ini terbilang sukses dalam pelaksanaannya. Program PEMP dilaksanakan bertujuan untuk meningkatkan kesejahteraan masya rakat pesisir melalui penguatan kelembagaan sosial ekonomi dengan mendayagunakan sumberdaya laut dan pesisir secara berkelanjutan.

Sejalan dengan program pemerintahan JOKOWI-JK saat itu, yaitu "Menjadikan Indonesia menjadi poros maritim dunia" yaitu dengan meningkatkan penguatan pembangunan maritim yang diiringi dengan menguatnya tuntutan demokratisasi dan peningkatan peranan masyarakat (stakeholders), pemerataan dan keadilan serta perhatian terhadap potensi laut dan keanekaragaman daerah. Melalui pembangunan poros maritim dengan mengembangkan wisata bahari di Indonesia harus memanfaatkan Indonesia sebagai Negara Maritim. Potensi maritim ini memiliki prospek besar, salah satunya dalam wisata bahari, sehingga sangat menguntungkan kedepan apabila pariwisata bahari di Indonesia dapat dikembangkan dengan baik dan professional.

Zamzami (2016) melakukan penelitian di Kabupaten Agam terhadap wisata bahari yang digerakkan oleh nelayan. Dalam penelitiannya menghasilkan kesimpulan besarnya peran nelayan dalam menguatkan gerak wisata bahari. Dampak yang dapat dirasakan masyarakat dengan adanya wisata bahari tersebut mendorong masyarakat untuk menumbuhkan 
ekonomi kreatif sebagai penunjang kearifan wisata. Selain itu, keberadaan wisata menjadi geliat diversifikasi wirausaha bagi masyarakat pesisir.

Ketiga, nelayan garda depan konservasi lingkungan. Kerusakan lingkungan yang terjadi di wilayah pantai/pesisir Indonesia hingga saat ini masih belum bisa ditanggulangi dengan baik dan optimal. Justru yang terjadi kerusakan lingkungan yang makin memperparah dan semakin meluas. Penyebab terjadinya kerusakan lingkungan di wilayah pesisir lebih didominasi oleh pencemaran-minyak, sampah dll, hal ini menyebabkan beberapa pesisir pantai di Indonesia kerusakan mangrove dan terumbu karang. Hal ini penting untuk dicermati mengingat $70 \%$ wilayah indonesia adalah kelautan. Penanganan yang cepat dalam persoalan konservasi lingkungan pesisir butuh melibatkan tenaga dengan akses yang cepat (Najmi et al., 2016). Hasil penelitian yang dilakukan oleh (Fauziah, 2018) di Desa Ketapang Kabupaten Tangerang menunjukkan abrasi yang terjadi di Desa Ketapang hingga tahun 2015 mencakup total luas $20.12 \mathrm{Ha}$. Hasil penelitian menunjukkan sebesar $66 \%$ nelayan terlibat aktif dalam menanggulangi dampak abrasi di desa tersebut dengan melakukan penanaman mangrove.

Keempat, nelayan basis sosial-kultur kearifan lokal masyarakat pesisir. Secara sosiologis, karakteristik masyarakat nelayan berbeda dengan krakteristik masyarakat petani, seiring dengan perbedaan karakteristik sumber daya yang dihadapi. Masyarakat petani menghadapi sumber daya terkontrol, yakni pengelolaan lahan untuk produksi suatu komoditas dengan output yang relatif bisa diprediksi. Dengan sifat produksi yang demikian memungkinkan tetapnya lokasi produksi sehingga menyebabkan mobilitas usaha yang relatif rendah dan elemen risiko pun tidak besar. Karakteristik tersebut berbeda sama sekali dengan nelayan. Nelayan menghadapi akses sumber daya yang hingga saat ini masih bersifat open access. Karakteristik sumber daya seperti ini menyebabkan nelayan mesti berpindahpindah untuk memperoleh hasil maksimal, yang dengan demikian elemen risiko menjadi sangat tinggi. Kondisi sumber daya yang berisiko tersebut menyebabkan nelayan memiliki karakter keras, tegas, dan terbuka (Satria, 2009).

Kompleksitas sosial budaya yang terjadi pada masyarakat nelayan, terutama berkaitan dengan beragamnya kelompok dan kategori sosial terlibat secara langsung atau tidak langsung dalam pemanfaatan sumberdaya dan lingkungan laut serta beragamnya sektor mata pencaharian terkait laut. 
Fenomena budaya bahari akan mencakup semua fenomena dan untuk pembatasan dan penyederhanaan subjek kajian kiranya dilakukan fokusfokus studi pada setiap atau beberapa fenomena social budaya yang kompleks tersebut. Hal tersebut telah memunculkan dinamika pranata sosial yang sangat mempengaruhi kepada kearifan lokal mereka. Kearifan local merupakan strategi adaptasi yang memang muncul dari dalam masyarakat itu sendiri dalam membenahi masalah-masalah social yang berkenaan dengan kehidupan masyarakat. Kearifan lokal ini tumbuh dari hasil interaksi antara masyarakat dan lingkungannya.

Hasil penelitian Zamzami (2016) Nagari Tiku Selatan, Kecamatan Tanjung Mutiara menunjukkan dinamika pranata sosial mampu memberikan kekuatan yang positif bagi nelayan dalam kehidupan keseharian mereka. Pranata social perikanan dalam hal ini mampu memberikan jawaban atas permasalahan di atas. Penguatan kelompok sosial nelayan melalui kelembagaan sosial merupakan suatu kebutuhan yang sangat mendesak dan mutlak diperlukan oleh nelayan, agar mereka dapat bersaing dalam melak sanakan kegiatan usaha perikanan dan dapat meningkatkan kesejahteraan hidupnya. Pranata sosial mempunyai peran yang penting dalam melestarikan tradisi-tradisi yang telah terbentuk sejak lama. Tradisi yang turun temurun mampu meningkatkan pengembangan masyarakat nelayan terutama kepada aspek kekerabatan dan ikatan emosional sesama nelayan.

Kelima, nelayan sebagai kekuatan ketahanan maritim. Negara kesatuan republik indonesia adalah negara kepulauan terbesar di dunia dengan jumlah pulau yang dimiliki mencapai 17.504 buah dengan wilayah laut yang mencapai 5.800.000 KM². Memiliki garis pantai terpanjang kedua di dunia sepanjang $81.000 \mathrm{~km}$, dengan letak geografisnya yang sangat strategis di antara 2 benua (Asia dan Australia) dan 2 samudera (Hindia dan Pasifik). Kondisi tersebut menempatkan Indonesia kaya akan sumber daya alam yang memiliki keanekaragaman hayati (Sadaraianto et al., 2018).

Namun luasnya wilayah laut yuridiksi nasional berbanding terbalik dengan jumlah unsur-unsur TNI AL yang dimiliki, keterbatasan jumlah dan kemampuan Alutsista untuk mampu melindungi keseluruhan luasnya perairan adalah merupakan salah satu faktor utama yang menghambat TNI AL untuk dapat melaksanakan tugas pokoknya secara optimal hingga saat ini. TNI AL sebagai komponen utama pertahanan negara di laut dalam kurun 
waktu menuju postur TNI AL yang ideal tersebut, membutuhkan adanya dukungan dan partisipasi dari kekuatan maritim nasional lainnya. Kekuatan yang mampu melapisi kekurangan jumlah Alutsista yang dapat dihadirkan di laut yang terdiri dari armada niaga, armada perikanan, pelabuhan, industri jasa maritim maupun unsur-unsur pendukung lainnya yang termasuk dalam kategori komponen pendukung pertahanan negara di laut. Keterlibatan unsur-unsur pendukung dalam bentuk dukungan secara langsung maupun tidak langsung kepada TNI AL dalam pelaksanaan tugas pokok mewujudkan kedaulatan Negara di laut guna mewujudkan tercapainya tujuan nasional.

Kehadiran di laut bertujuan untuk menangkal tindakan-tindakan yang bermaksud akan melakukan tindakan secara sepihak yang dapat merugikan kepentingan negara dan bangsa Indonesia dan di sisi lain yang dapat menguntungkan pihak/negara lain. Tindakan yang merugikan itu di antaranya hilangnya kedaulatan wilayah hingga tereksploitasinya kekayaan alam Indonesia secara ilegal. Menghadirkan kekuatan TNI AL pada masa damai adalah untuk dapat mengendalikan laut yang dapat menjamin digunakannya media laut oleh para pengguna yang selalu tunduk dan taat pada ketentuan hukum laut internasional dan nasional yang berlaku.

Pemberdayaan terhadap komunitas nelayan selain untuk meningkatkan kesejahteraan hidup yang berarti mengentaskan mereka dari garis kemiskinannya, juga dapat berarti menanamkan dan meningkatkan kesadaran bela negara. Kesadaran bela negara dalam bentuk rasa ingin untuk menjaga dan mengamankan keutuhan wilayah yuridiksi perairan nasional dari ancaman musuh dan para pelaku pelanggar hukum di laut. Rasa bela negara semestinya harus dimiliki oleh seluruh warga negara Indonesia tanpa terkecuali, termasuk para nelayan yang menggantungkan hidupnya dari media laut.

Nelayan dengan segala permasalahan sosial ekonomi yang masih dan selalu menyertainya, merupakan suatu entry point bagi TNI AL untuk dapat melaksanakan perberdayaan wilayah pertahanan laut guna menjamin terlaksananya tugas TNI matra laut di bidang pertahanan. Celah yang sedemikian kecil dan sempit itu akan memberikan suatu dampak yang demikian dahsyat, besar dan menguntungkkannya bila pihak-pihak yang terkait mampu secara tepat memberdayakannya. Tepat dalam pemberdayaannya adalah tercapainya kesesuaian antara meminimalkan 
kelemahan akan penguasaan teknologi dengan kepedulian dan kearifan pemerintah dalam bentuk pembangunan di sektor maritim secara lebih terarah dan terprogram (Sadaraianto et al., 2018).

Peran Indonesia yang dalam hal ini diwakili oleh TNI AL dalam menciptakan stabilitas di kawasan Asia Tenggara adalah dengan menjamin keamanan seluruh perairan yuridiksi nasional dari bahaya ancaman kekerasan, pelanggaran hukum, penggalian sumber daya alam secara ilegal dan navigasi. Terwujudnya jaminan keamanan tersebut dapat memberikan daya tangkal terhadap kekuatan-kekuatan musuh yang berkepintingan dan berkehendak dalam pemanfaatan sumber daya di laut secara sepihak.

Pengembangan masyarakat nelayan melalui penguatan pranata sosial perikanan merupakan suatu upaya pemberdayaan terencana yang dilakukan secara sadar dan sungguh-sungguh melalui usaha bersama nelayan untuk memperbaiki keragaman sistem perekonomian masyarakat pedesaan. Arah pemberdayaan nelayan akan disesuaikan dengan kesepakatan yang telah dirumuskan bersama. Dengan partisipasi yang tinggi terhadap kelembagaan nelayan, diharapkan rasa ikut memiliki dari masyarakat atas semua kegiatan yang dilaksanakan akan juga tinggi. Keberhasilan penerapan suatu pranata sosial nelayan tidak semata-mata diukur dengan nilai tambah ekonomi, namun harus mempertimbangkan peran dan fungsi nilai-nilai sosio-kultural secara utuh.Dari pemaparan ini maksudnya adalah sektor perikanan dan kelautan yang salah satunya digerakkan oleh nelayan memiliki sumbangsih terhadap penguatan ekonomi daerah dan negara. Hanya saja butuh perhatian khusus agar dapat lebih meningkatkan perolehan derajat ekonomi yang lebih signifikan, mengingat betapa luasnya potensi kemaritiman indonesia jika dibandingkan dengan negara-negara lain.

Dalam upaya membangun masyarakat nelayan yang kondisinya seperti di atas dan agar potensi pembangunan masyarakat bisa di kelola dengan baik, maka salah satu strategi yang harus di tempuh adalah dengan membangun dan memperkuat usaha kelompok mikro dan mengembangkan kualitas SDM, dengan jalan meningkatkan wawasan pembangunan dan keterampilan ekonomi masyarakat. Dengan demikian, di harapkan masyarakat secara kolektif memiliki kemampuan optimal dalam membangun wilayahnya dan mengembangkan potensi sumber daya alam yang di miliki. 
Masyarakat nelayan atau masyarakat pesisir di Kecamatan Paiton, Kabupaten Probolinggo menghadapi dilema pembangunan di atas, padahal kawasan pesisir memiliki potensi sumber daya alam besar, khususnya potensi sumber daya pesisir, perikanan, dan kelautan. Potensi ini belum tergarap secara optimal dan berkelanjutan. Sedangkan masyarakat khususnya yang tinggal di kawasan pesisir, Kecamatan Paiton masih berada dalam angka tingkat pengangguran yang tinggi.

Atas dasar kekurangan di atas, kegiatan-kegiatan pendampingan untuk pemberdayaan ekonomi sangat diperlukan agar masyarakat memiliki kemampuan dalam mengelola potensi sumber daya ekonomi lokal secara optimal dan berkelanjutan. Pengembangan kemampuan ekonomi masyarakat diperlukan untuk masa depan pembangunan Kecamatan Paiton agar mereka dapat memanfaatkan potensi lokal dan terciptanya kesejahteraan dalam bidang ekonomi. Oleh karena itu, sebagai insan akademik Universitas Nurul Jadid yang memiliki kewajiban dalam melakukan pengabdian kepada masyarakat, maka ikut serta berperan dalam pemberdayaan ekonomi masyarakat dengan harapan dapat membantu mengurangi pengangguran dan menciptakan kesejahteraan ekonomi dan sosial di wilayah pesisir Kecamatan Paiton.

\section{Metode}

Pemberdayaan masyarakat pesisir ini diawali dengan penelitian deskriptif melalui studi kasus. Metode deskriptif adalah suatu metode dalam meneliti status sekelompok manusia, suatu objek, kondisi, sistem pemikiran ataupun suatu peristiwa pada masa sekarang dengan tujuan untuk membuat deskripsi, gambaran atau lukisan secara sistematis, faktual dan akurat mengenai fakta-fakta, sifat-sifat serta hubungan antar fenomena yang diselidiki baik secara kuantitatif ataupun kualitatif Sedangkan studi kasus atau penelitian kasus adalah penelitian tentang status subjek penelitian yang berkenan dengan suatu fase spesifik atau khas (Nazir, 1999).

Pada model pemberdayaan masyarakat pesisir dengan menggunakan Training for Rural Economic Empowerment (TREE) merupakan metodologi pemberdayaan ekonomi kelompok prasejahtera. TREE berfokus pada peran penting pengembangan keterampilan dalam menciptakan kesempatan kerja. 
TREE memiliki fokus khusus pada peningkatan masa depan orang-orang dengan tingkat melek huruf dan angka yang rendah yang tinggal di daerah pedesaan, khususnya perempuan. Metodologi TREE terdiri dari serangkaian proses yang dirancang untuk memandu penciptaan inisiatif pembangunan ekonomi lokal. Proses-proses tersebut mencakup bagaimana mengidentifikasi secara sistematis peluang-peluang yang menghasilkan pendapatan di tingkat lokal; merancang dan memberikan program pelatihan keterampilan yang sesuai dan memberikan dukungan pasca pelatihan yang diperlukan, misalnya, akses ke pasar. Model TREE mendorong peningkatan dan pembangunan daerah berdasarkan potensi sumber daya dan peningkatan keterampilan serta pengetahuan untuk menciptakan peluang ekonomi dan lapangan kerja baru, ke arah kegiatan ekonomi yang berkelanjutan (ILO, 2009).

Program pemberdayaan ini dirancang untuk dengan sasaran masyarakat miskin, perempuan yang terpinggirkan dengan literasi rendah, pemuda yang kurang beruntung dan pengangguran, orang dengan tingkat pendidikan rendah, penyandang disabilitas dan kelompok rentan yang berada di wilayah pesisir Paiton.

Tahapan dalam melaksanakan program pemberdayaan melalui TREE ini sebagai berikut:

\section{TREE}

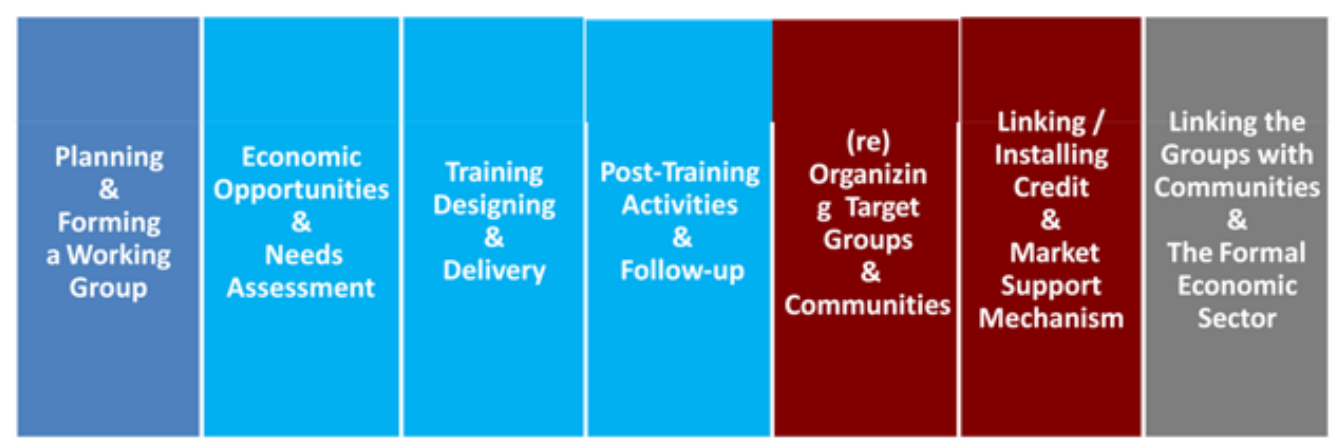

Monitoring \& Evaluasi

\begin{tabular}{l|l|l}
\hline START-UP & ECONOMIC SECTOR & EXPAND \\
\hline
\end{tabular}

Bagan 1. Tahapan model TREE

Sumber: Rural skills training: A Generic Manual On Training For Rural Economic

Empowerment, ILO 2009 


\section{Hasil}

Selama pelaksanaan program pembedayaan dengan model TREE ini dapat mengembangkan beberapa sektor diantaranya: ekonomi, sosial, budaya, pendidikan, lingkungan dan kesehatan. Sektor-sektor tersebut menjadi sasaran karena penting dalam menciptakan keberlangsungan pembanguan masyarakat desa. Secara rinci wujud dari pembangunan sektor-sektor tersebut sebagai berikut:

a. Bidang Ekonomi

Dalam bidang ekonomi program pemberdayaan masyarakat pesisir ini bersama nelayan melakukan kegiatan pengolahan hasil ikan yang memiliki nilai ekonomi berupa: pengolahan hasil ikan laut yang berbentuk frozen food, krupuk ikan, rengginang, abon, naget, kecap, terasi, pastel ikan, sumpia ikan, cookies ikan dan berbagai olahan ikan siap saji. Termasuk juga kerajinan resin dan fiber diantaranya; Merchandise dan Aksesoris Rumah Tangga. Terkait dengan penjulan program ini memanfaatkan media bazar nelayan, membuka outlet dan pemanfaatan marketplace.

b. Bidang Sosial

Pada sisi penggarapan bidang sosial program ini dapat membentuk kelompok nelayan: budidaya, tangkap, dan konservasi. Selain itu juga kelompok Rukun Tetangga dan kelompok arisan.

c. Bidang Budaya

Pada sektor budaya, program ini mengembangkan kegiatan sedekah laut, hadrah, diskusi Mellak Ate dan peringatan hari nelayan.

d. Bidang Keagamaan

Pada bidang keagamaan, program ini dapat menghidupkan kegiatan sarwaan, sholawatan, pengajian rutinan dan peringatan hari besar Islam.

e. Bidang Pendidikan dan Pelatihan

Pada bidang ini bersama masyarakat, program ini dapat memunculkan sekolah tingkat pendidikan anak usia dini (PAUD), sekolah madrasah ibtidaiyah dan madrasah tsanawiyah yang saat berada dibawah naungan Yayasan Pesantren Nurul Jadid. 


\section{f. Bidang Lingkungan}

Bidang lingkungan digarap bersama masyarakat bekerjasama dengan pemerintahan desa dan CSR perusahaan sekitar Paiton dengan melakukan konservasi mangrove di sepanjang pesisir Paiton beserta melakukan konservasi Cemara Laut

g. Bidang Kesehatan

Pada bidang ini terdapat beberapa hasil kegiatan diantaranyya penyuluhan pola hidup bersih, pengobatan gratis dan sunat masal.

\section{Pembahasan}

\section{Profil Pesisir Paiton}

Wilayah pesisir Paiton terletak pada lintang $7041^{\prime} 58^{\prime \prime}-7043^{\prime} 07^{\prime \prime}$ LS dan 1130 30' 55" - 1130 36' 26" Bujur Timur. Wilayah seluas 5.325, 25 Ha ini secara administratif terdiri dari 20 desa dan 72 dusun dengan jumlah penduduk 65.951 jiwa. Ibukota Kecamatan Paiton berada pada 6 meter di atas permukaan air laut. Kecamatan Paiton berada pada ketinggian 0 sampai 250 meter di atas permukaan air laut.

Jumlah pemilik kapal dan nelayan di pesisir paiton dari data pendamping desa ada sekitar 1803 dengan rata-rata perolehan tangkapan 420 ton/bulan. jenis penyumbang produksi terbanyak adalah jenis kembung, selar kuning, peperek dan teri. Adapun perincian profil nelayan pesisir paiton berdasarkan data yang dirilis oleh Pendamping Desa Kecamatan Paiton sebagai berikut:

1. Pemilik kapal jurung Jumlah $: 250$

Kapal $: 250$

Alat tangkap : : 750

Hasil tangkapan : 350 ton/bulan
2. Nelayan Jumlah $: 1553$

Alat tangkap : $: 650$

Perahu : 650

Hasil tangkapan : 70 ton/ bulan

3. Petani tambak

Hasil tambak : udang, bandeng, mujaer, garam

Selain itu ada hal yang penting untuk disikapi terkait dengan garis pantai yang terus menjorok ke daratan. Dalam kajian garis pantai diketahui perubahan garis pantai dari tahun 1993-1996 dan 1996-2009. Perubahan 
garis pantai yang terjadi di daerah pantai Kecamatan Paiton tahun 1993-1996 lebih dominan disebabkan oleh proses abrasi pantai sebesar 56,1 ha. Abrasi tersebut menyebabkan perubahan penggunaan lahan yakni sawah 658,158 ha, hutan 193,744 ha dan industri 15,125 ha. Perubahan garis pantai tahun 1996 - 2009 berkaitan dengan proses abrasi pantai yang menyebabkan perubahan luas lahan sebesar 12,4927 ha. Abrasi tersebut menyebabkan luas penggunaan lahan menjadi berkurang. Penggunaan lahan yang terkena abrasi adalah lahan tegalan, industri dan tambak, masing-masing sebesar 870,903 ha, 73,667 ha dan 85,9307 ha (Prameswari et al., 2014).

\section{Aplikasi Model TREE di Wilayah Pesisir Paiton}

Langkah awal model TREE dengan penerapan planning and forming working group adalah dengan membentuk kelompok kerja di tingkat kecamatan dan desa yang dijadikan sasaran pemberdayaan masyarakat. Langkah ini secara teknis dengan membentuk satuan kerja dari unsur (1) pemerintahan kecamatan dan desa (pemanfaatan dana desa) (2) korporasi swasta (pragram CSR/corporate social responcibility) dan penyedia jasa pengembangan bisnis (3) lembaga non pemerintah: asosiasi pengusaha (4) lembaga donor: program pemberdayaan masyarakat (5) komunitas: pesantren dan kelompok ekonomi dan budaya di desa.

Langkah berikutnya adalah penerapan ecconomic opportunities and need assessment, training designing and delivery serta post training activities and follow up yang didukung dengan star up economic sector.

\section{Ecconomic opportunities and need assessment}

Pada tahap ini, langkahnya adalah dengan melakukan rapid community assessment (RCA) meliputi kegiatan berupa: (1) membuat profil komunitas (usia, pendidikan dan keterampilan, gender dan pengalaman kerja), (2) menentukan stakeholder; pemerintah, swasta, lembaga swadaya masyarakat (LSM) dan lembaga donor. (3) menelaah permintaan konsumen (4) peluang pasar (5) Potensi kegiatan ekonomi baru, serta (6) melakukan studi kelayakan terhadap hal yang telah disebutkan sebelumnya. 
2. Training designing and delivery

Tahap ini adalah tahap pelatihan. Pada tahap ini masyarakat diajak untuk melakukan kegiatan berikut: (1) menganalisis kebutuhan pelatihan (2) menentukan sistem, metodelogi dan desain pelatihan (3) membuat pelatihan keterampilan di balai besar, lembaga pelatihan dan keterampilan (4) melaksanakan pelatihan kewirausahaan: start your business, start your green business, get ahead (5) membuat literasi keuangan: pendidikan keuangan pendamping komunitas: pendampingan partisipatif.

\section{Post training activities and follow up}

Tahap ini berupa dukungan pendampingan setelah pelatihan, yakni dengan menentukan alternatif pendamping komunitas yang telah dibentuk. Alternatif tersebut telah ditentukan diantaranya (1) pendamping masyarakat non pemerintah (2) jaringan pendamping pemerintah terkait (3) komunitas wirausaha (5) usaha kecil (business-to-business) (5) penyedia jasa layanan pengembangan bisnis (incubator bisnis, asosiasi pengusaha dan sejenisnya)

Setelah melaksanakan penerapan ecconomic opportunities and need assessment, training designing and delivery serta post training activities and follow up yang didukung dengan star up economic sector; langkah berikutnya adalah penerapan (re) organizing target group and communities, linking/installing credit and market support mechanism (dua tahap ini adalah bagian dari pengembangan/expand) dan linking the groups with communities and the formal economic sector (tahap ini ada bagian dari tahap yang ditandai dengan keberlanjutan/sustain). Hasilnya jika dibentuk bagan akan tergambar sebagai berikut: 


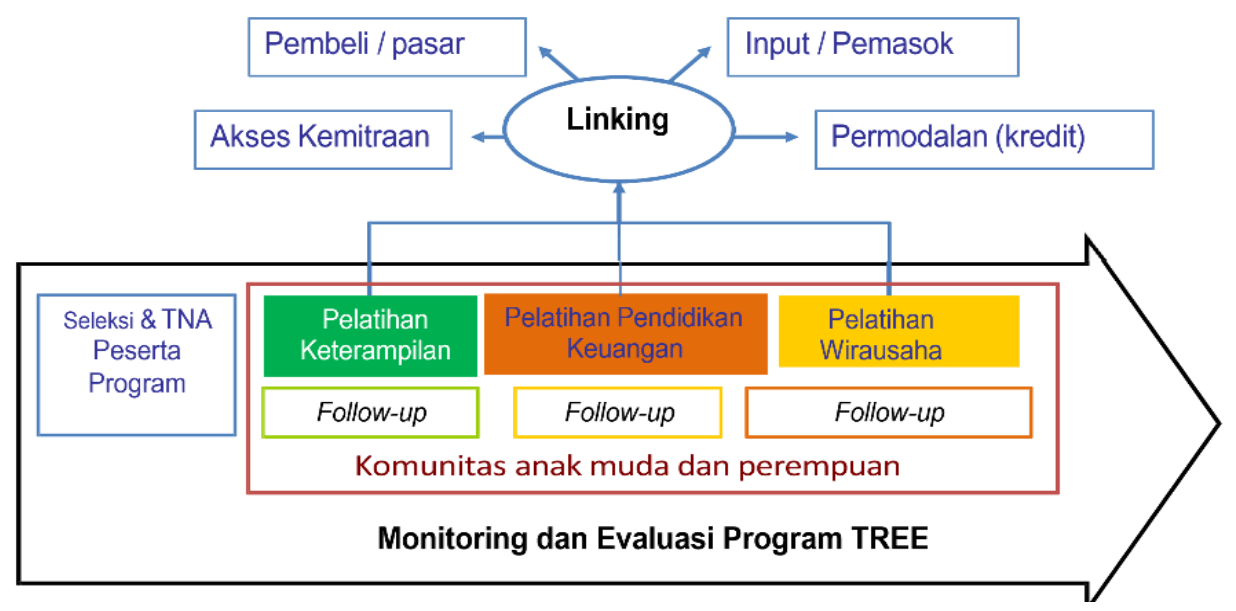

Gambar 2. Skema pendampingan komunitas

Skema pendampingan di atas didukung dengan pendampingan komunitas berupa: penguatan kapasitas kelompok; fasilitas program: program kewirausahaan dan dukungan stakeholder; rujukan dan akses pemasaran, permodalan dan faktor input; serta kemitraan (jejaring) lokal/nasional/ internasional.

Ke semua langkah yang telah dipaparkan dalam diskusi pembahasan ini, setelah dilakukan pengkajian langkah-langkah program dan evaluasi terhadap segala persoalan yang muncul selama masa menjalankan program pemberdayaan model TREE di masyarakat pesisir Paiton, akan dapat berjalan dengan lebih baik jika terdapat skema bangunan pengembangan yang mengarah pada peningkatan kualitas hidup sebagaimana digambarkan dalam bagan berikut:

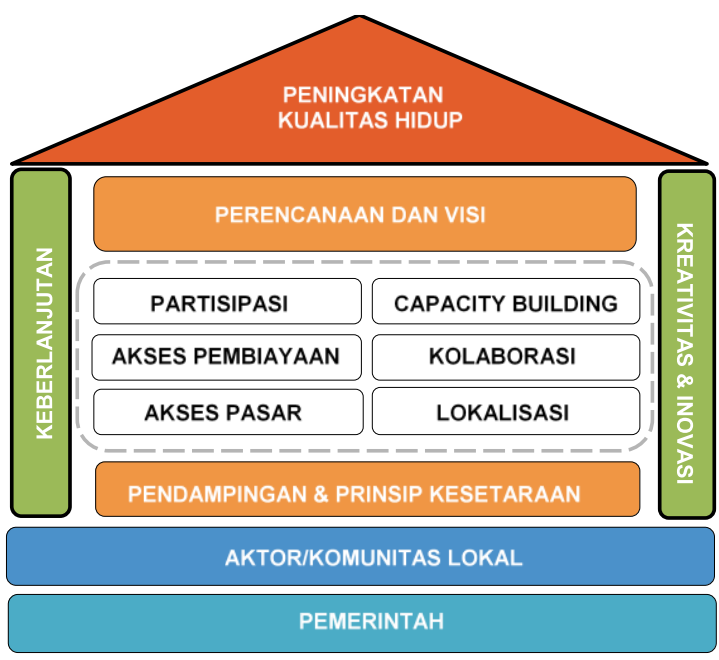

Gambar 3. Prinsip pendampingan peningkatan kualitas hidup 
Prinsip pendampingan yang menjadi arah dari program pemberdayaan masyarakat pesisir Paiton ini (sebagaimana dalam gambar 3) dapat berjalan dengan baik jika dilakukan hal-hal berikut : (1) meningkatkan partisipasi dan keterlibatan penerima manfaat dalam program, terutama perempuan dan anak muda (2) mendesain program/pelatihan sesuai kebutuhan target sasaran (3) melibatkan stakeholder lokal untuk keberlanjutan (4) mengoptimalkan potensi lokal (5) mengembangkan jaringan terpadu (akses pemasaran, keuangan, peningkatan kapasitas, dan perijinan) dan (6) adanya dukungan paska pelatihan.

Secara berurutan setiap angka yang terdapat pada dalam kurung "()" tersebut dapat ditindak lanjuti dengan (1) identifikasi peluang ekonomi dan training needs assessment (TNA) (2) pelatihan perencanaan bisnis (3) pelatihan pengelolaan keuangan keluarga (4) metodologi pelatihan dan pendampingan (5) ekosistem mapping, dan (6) melakukan monitoring dan evaluasi.

Turunan dari tahap di atas secara berurutan pula menghasilkan langkah berikut (1) mengenal pendekatan pemberdayaan ekonomi dan bagaimana merancang kebutuhan pelatihan (2) dan (3) Membedah struktur modul perencanaan bisnis yang berbasis peluang pasar dan pentingnya perencanaan keuangan keluarga sebagai fondasi (4) mengenal lebih dekat metode pelatihan dan pendampingan yang dapat meningkatkan partisipasi penerima manfaat (5) mengidentifikasi enabling environment bagi wirausaha (6) bagaimana mengukur tingkat keberhasilan suatu kegiatan/program.

Beberapa hal tersebut jika dibagankan akan muncul sebagai berikut:

\begin{tabular}{|l|}
\hline 1) Meningkatkan partisipasi dan \\
keterlibatan penerima \\
manfaat dalam program, \\
terutama perempuan dan anak \\
muda \\
2) Mendesain program/pelatihan \\
sesuai kebutuhan target \\
sasaran \\
3) Melibatkan stakeholder lokal \\
untuk keberlanjutan \\
4) Mengoptimalkan potensi lokal \\
5) Mengembangkan jaringan \\
terpadu (akses pemasaran, \\
keuangan, peningkatan \\
kapasitas, dan perijinan) \\
6) Dukungan paska pelatihan \\
\hline
\end{tabular}

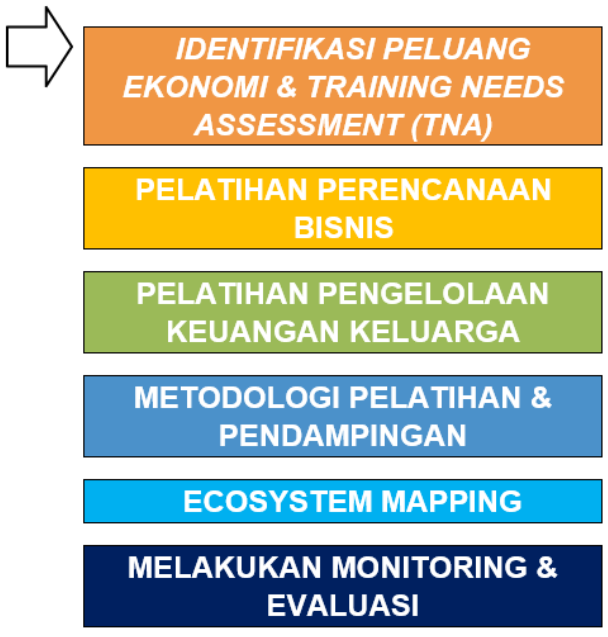




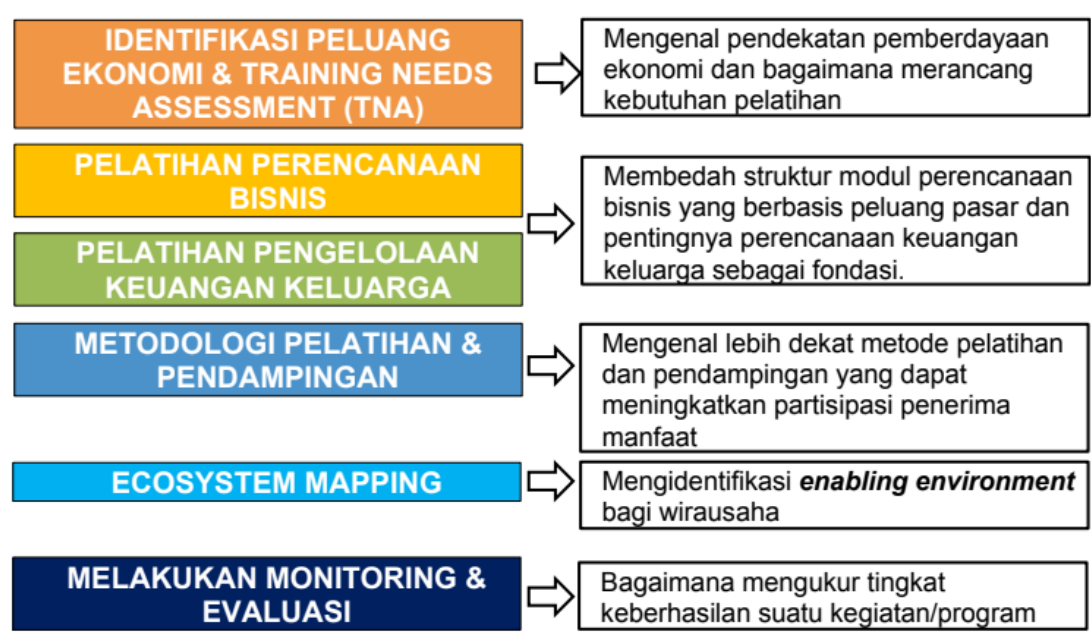

Gambar 4. Langkah-langkah skema pendampingan

\section{Penutup}

Pemberdayaan masyarakat pesisir di wilayah Paiton dengan bantuan penerapan model TREE telah berdampak dalam memberdayakan masyarakat miskin pedesaan dengan:

1. membantu mereka meningkatkan kemampuan mereka untuk menggunakan pengetahuan dan keterampilan mereka secara efektif di lingkungan tempat mereka tinggal dan bekerja;

2. memberi mereka keterampilan tambahan dan dukungan lain yang diperlukan untuk meningkatkan pendapatan dan produktivitas, dan untuk memperbaiki kondisi kehidupan;

3. memberi masyarakat peluang untuk berkontribusi dan mengambil manfaat dari tindakan kolektif dan berkembang sendiri.

Dalam program pemberdayaan ini telah menerapkan pendekatan pembangunan yang memastikan perempuan dan laki-laki miskin mendapatkan sumber daya yang tidak akan pernah hilang yaitu keterampilan dan pengetahuan yang dapat mereka terapkan untuk meningkatkan pendapatan mereka dan mengambil peran lebih aktif dalam membentuk komunitas mereka. Pendekatan pembangunan lokal dan gender sangat diarusutamakan ke dalam program TREE dan oleh karena itu berkontribusi pada pemberdayaan perempuan dan laki-laki. Sehingga masyarakat pesisir Paiton dapat berperan dalam pembangunan desanya melalui berbagai bidang diantaranya: ekonomi, budaya, sosial, keagamaan, pendidikan, lingkungan dan kesehatan. 


\section{Referensi}

Fauziah, H. (2018). Dampak Abrasi Terhadap Peningkatan Partisipasi Masyarakat Dalam Penanaman Mangrove Di Desa Ketapang, Kecamatan Mauk, Kabupaten Tangerang-Banten. Universitas Islam Negeri Syarif Hidayatullah.

ILO. (2009). Rural skills training: A generic manual on training for rural economic empowerment. International Labour Office.

Najmi, N., Boer, M., \& Yulianda, F. (2016). Coral Reef Ecosystem Management in Area of Eastern Coastal Water Conservation Weh Island Sabang. Jurnal IImu Dan Teknologi Kelautan Tropis, 8(2), 781-790.

Nazir, M. (1999). Metode Penelitian. Ghalia.

Nugroho, M. (2015). Pemberdayaan masyarakat nelayan di kabupaten Pasuruan: kajian pengembangan model pemberdayaan sumberdaya manusia di wilayah pesisir pantai. Teknologi Pangan: Media Informasi Dan Komunikasi Ilmiah Teknologi Pertanian, 6(1).

Prameswari, S. R., Anugroho, A., \& Rifai, A. (2014). Kajian Dampak Perubahan Garis Pantai terhadap Penggunaan Lahan berdasarkan Analisa Penginderaan Jauh Satelit di Kecamatan Paiton, Kabupaten Probolinggo Jawa Timur. Journal of Oceanography, 3(2), 267-276.

Retnowati, E. (2011). Nelayan Indonesia dalam Pusaran Kemiskinan Struktural (Perspektif Sosial, Ekonomi dan Hukum). Perspektif, 16(3).

Sadaraianto, S., Anwar, S., \& Purwanto, P. (2018). Pengaruh Pemberdayaan Wilayah Maritim dan Pelatihan Nelayan Terhadap Kesejahteraan Masyarakat Pesisir Dalam Rangka Mengoptimalkan Strategi Pertahanan di Desa Gisik Cemandi Kabupaten Sidoarjo. Strategi Perang Semesta, $4(3)$.

Satria, A. (2009). Pesisir dan Laut Untuk Rakyat. IPB Press.

Zamzami, L. (2016). Dinamika Pranata Sosial Terhadap Kearifan Lokal Masyarakat Nelayan Dalam Melestarikan Wisata Bahari. JURNAL ANTROPOLOGI: Isu-Isu Sosial Budaya, 18(1), 57-67. 